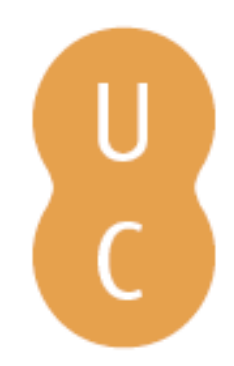

\title{
nombalina
}

\section{Safety zones and convective heat: numerical simulation of potential burn injury from heat sources influenced by slopes and winds}

Autor(es): $\quad$ Parsons, Russell A.; Butler, Bret. W.; Mell, William "Ruddy"

Publicado por: Imprensa da Universidade de Coimbra

URL

persistente: URI:http://hdl.handle.net/10316.2/34217

DOI: $\quad$ DOI:http://dx.doi.org/10.14195/978-989-26-0884-6_165

Accessed : $\quad$ 26-Apr-2023 07:21:34

A navegação consulta e descarregamento dos títulos inseridos nas Bibliotecas Digitais UC Digitalis, UC Pombalina e UC Impactum, pressupõem a aceitação plena e sem reservas dos Termos e Condições de Uso destas Bibliotecas Digitais, disponíveis em https://digitalis.uc.pt/pt-pt/termos.

Conforme exposto nos referidos Termos e Condições de Uso, o descarregamento de títulos de acesso restrito requer uma licença válida de autorização devendo o utilizador aceder ao(s) documento(s) a partir de um endereço de IP da instituição detentora da supramencionada licença.

Ao utilizador é apenas permitido o descarregamento para uso pessoal, pelo que o emprego do(s) título(s) descarregado(s) para outro fim, designadamente comercial, carece de autorização do respetivo autor ou editor da obra.

Na medida em que todas as obras da UC Digitalis se encontram protegidas pelo Código do Direito de Autor e Direitos Conexos e demais legislação aplicável, toda a cópia, parcial ou total, deste documento, nos casos em que é legalmente admitida, deverá conter ou fazer-se acompanhar por este aviso.

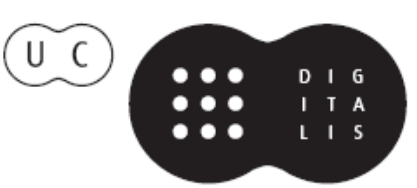




\section{ADVANCES IN}

Forest Fire

\section{RESEARCH}

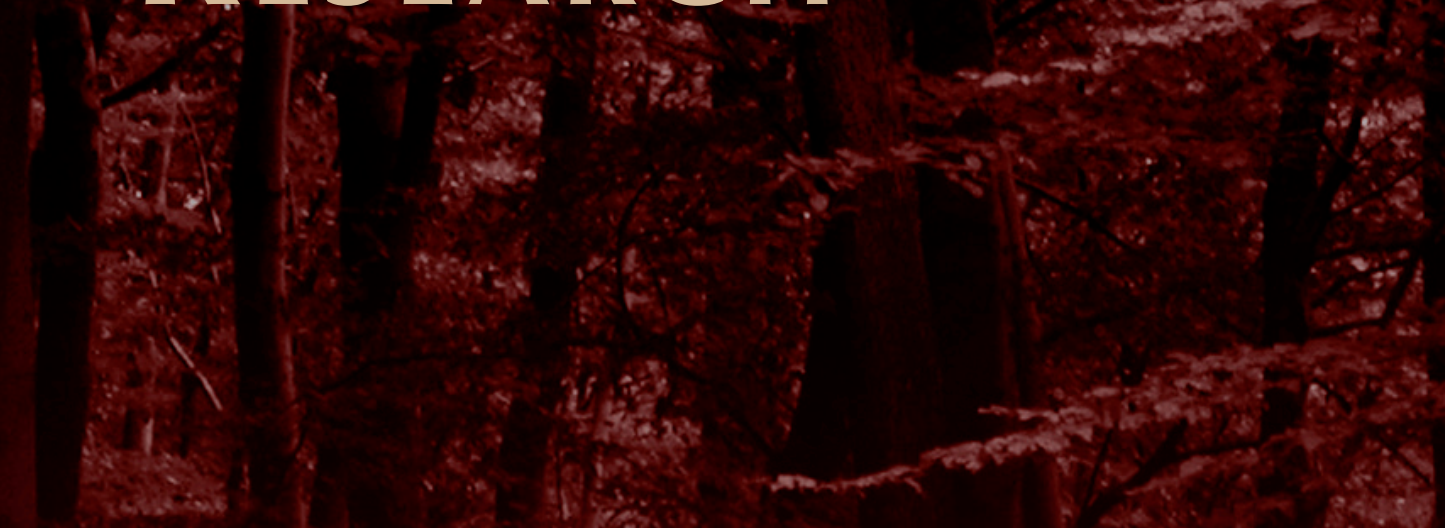

\section{DOMINGOS XAVIER VIEGAS}

\section{EDITOR}




\title{
Safety zones and convective heat: numerical simulation of potential burn injury from heat sources influenced by slopes and winds
}

\author{
Russell A. Parsons a, Bret. W. Butler", William “Ruddy” Mellc \\ ${ }^{a}$ USDA Forest Service RMRS Fire Sciences Laboratory, 5775 Highway 10 W. Missoula, MT 59808, \\ rparsons@fs.fed.us \\ ${ }^{b}$ USDA Forest Service RMRS Fire Sciences Laboratory, 5775 Highway 10 W. Missoula, MT 59808, \\ bwbutler@fs.fed.us \\ ${ }^{c}$ USDA Forest Service PNW Pacific Wildland Fire Sciences Laboratory, 400 N. 34th St. Suite \\ 201 Seattle, WA 98103 wemell@fs.fed.us
}

\begin{abstract}
Although slope and winds are common factors in most wildland fires, current guidelines for safety zone dimensions used in the United States assume flat ground and do not consider wind speed as a factor. Similarly, while convective heat transfer is an essential part of fire behavior and is often highly significant to firefighter safety, it has not been considered in past work establishing safety zone criteria. In recent years, 3D, dynamic, physics-based dynamic fire models have been developed which can help us to understand fire behavior and firefighter safety. Here, we used a 3D dynamic fire model, WFDS, to explore different factors influencing potential burn injuries that could arise from both radiative and convective heat transfer over a range of heat sources, slopes and wind speeds. In the present study, we considered a fixed (non-moving) heat source on an inclined plane. Above this heat source, at regular intervals along the slope, synthetic "sensors" tracked wind velocities, temperature, radiative and total heat fluxes, facilitating analysis of potential burn injury as a function of distance from the heat source, analogous to the radius of a safety zone. Our primary finding was that convective heat could result in burn injuries at distances several times what would result from radiation alone. We also found that, while all factors were important, the nature of the heat source (heat release rate per unit area, flaming zone depth and residence time) had more pronounced effects on potential burn injury than slope or wind speed. Both of these findings have significant implications for how we think about firefighter safety, both in terms of how big safety zones might need to be to protect firefighters from convective heat, and in terms of characterizing the fuel as a heat source. This is a new arena of research investigation, and our work is just an early step; more work is needed to fully understand the implications of convective heat for firefighter safety and decision support.
\end{abstract}

Keywords: Firefighter safety zones, fire behaviour, fire safety, fire modeling

\section{Introduction}

The United States Forest Service defines safety zones as "a preplanned area of sufficient size and suitable location that is expected to protect fire personnel from known hazards without using fire shelters" (National Wildfire Coodinating Group 2004). Subsequent definitions in 2012 added detail and broadened this concept to include safety zones more typically encountered operationally, "an area cleared of flammable materials used for escape in the event the line is outflanked or in case a spot fire causes fuels outside the control line to render the line unsafe. In firing operations, crews progress so as to maintain a safety zone close at hand allowing the fuels inside the control line to be consumed before going ahead. Safety zones may also be constructed as integral parts of fuelbreaks; they are greatly enlarged areas which can be used with relative safety by firefighters and their equipment in the event of blowup in the vicinity." (National Wildfire Coodinating Group 2012).

Although institutional culture and policy, firefighter safety training and tactical approaches have significantly improved over the years, often in response to firefighter fatality incidents (e.g. McArdle 1957), recent tragedies such as the June 2013 Yarnell Hill fire in Arizona underscore the ongoing need 
for continued improvement in consideration of the potential risk exposure of firefighting personnel in wildland fire incidents and how such risks can be mitigated.

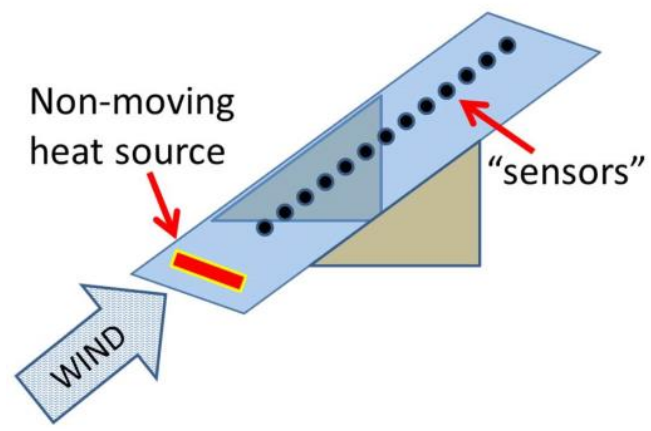

Figure 1. Schematic diagram of general experiment, consisting of a heat source at the lower end of an inclined plane. Above the heat source, sensors record key quantities used to evaluate incident heat flux. Slope was modeled through modification of the gravity vector rather than as shown here.

Most of the firefighter fatality or near-fatality events that have occurred in the United States and elsewhere over the last several decades have taken place in conditions in which slope and winds significantly influenced observed fire behaviour. Well documented examples include, among many others, the August 1949 Mann Gulch (Rothermel 1993), the 1994 South Canyon (Butler et al 1998), and the July 2001 Thirtymile fires (USDA Forest Service 2001) in the US; the 2003 Freixo de Espadaa-Cinta fire in Portugal (Viegas et al 2005), the 1998 Kareas fire in Greece (Xanthroupolous 2007), as well as the 1983 Grays Point, 1998 Johnstones Creek and 1998 Linton fires in Australia (Cheney et al 2001).

While slope and wind have been recognized as critical factors in fire behaviour for some time (Rothermel 1972), most research work examining safe separation distance characterizing safety zone dimensions to date has focused on radiation as the primary mechanism of heat transfer (Albini 1986, Rossi et al 2011, Zarate 2008); convection has often been considered as a less significant influence, with a common assumption that the buoyancy of heated gases would result in vertical transport, reducing the effect on persons or objects located some distance laterally from the flames (e.g. Gettle and Rice 2002). Consequently, current guidelines for safety zone dimensions used in the United States assume flat ground and do not consider wind speed as a factor (Butler and Cohen 1998a, 1998b). Recent work, however, suggests that convective heat transfer is more important to fire behaviour than had been thought in the past (Frankman et al 2010, Frankman et al 2012), with potentially significant implications for firefighter safety. A recent review of safety zones and entrapment incidents suggests that safety zone specifications can be improved through inclusion of convection (Butler 2014).

In recent years, dynamic fire behavior models have emerged which model the dominant physical processes driving fire behavior; unlike simpler semi-empirical models (e.g. Rothermel 1972), different mechanisms of heat transfer are modeled, facilitating detailed analysis of the roles and impacts of radiation and convection in fire behavior. Two such models are HIGRAD/FIRETEC (Linn et al 2002; Linn and Cunningham 2005; Linn et al 2007) and WFDS (Mell et al 2007; Mell et al 2009). Due to their dynamic nature, these models offer potentially valuable insights in examining interactions between fire, the atmosphere, vegetation, and topography to help improve our understanding of fire behavior and firefighter safety.

Our objective in this study was to use a physics-based fire model, WFDS, to explore the relative impact of different factors influencing potential burn injuries over a range of heat sources, slopes and wind speeds. A secondary objective was to assess the relative contribution of radiative vs convective heat in potential burn injury over a range of conditions. Using thermal dosage, an integrative measure based on magnitude and duration of exposure (Eisenberg et al 1975) which has been correlated to different burn injuries (Hymes et al 1996), we examined potential burn injuries resulting from either radiative 
or convective heat alone, or both mechanisms of heat transfer in combination, over a range of distances from the heat source.

\section{Methods}

Using WFDS, we carried out 288 simulations with a rectangular domain measuring $252 \mathrm{~m}$ in length, $40 \mathrm{~m}$ wide in width and $35 \mathrm{~m}$ in height, with a constant resolution of $1 \mathrm{~m}$ in $\mathrm{x}, \mathrm{y}$ and $\mathrm{z}$ dimensions. These experiments spanned a range of levels for several key factors, two representing key aspects of the fire environment (slope and wind) and three representing key aspects of the heat source, presented in Table 1, below. Our simulations spanned environmental conditions ranging from no-wind, no-slope up to substantial winds $(10 \mathrm{~m} / \mathrm{s})$ on $50 \%$ slope.

Table 1. Factors used in numerical experiments examining safe separation distance from a non-moving heat source. For each factor, the number of different levels is presented in parentheses before the values.

\begin{tabular}{lll} 
Factor Group & Factor and units & Levels \\
\hline Environment & Slope $(\%)$ & (6) $0,10,20,30,40,50$ \\
\hline Environment & Wind speed, $\mathrm{m} / \mathrm{s}^{\text {Heat Source }}$ & (4) $0,2.5,5,10$ \\
\hline Heat Source & Heat Area Depth $(\mathrm{m})$ & (2) 5,10 \\
\hline Heat Source & Duration $(\mathrm{s})$ & (2) 30,60 \\
\hline
\end{tabular}

We used mirror boundary conditions on lateral boundaries to emulate a fireline of infinite width; the ceiling boundary was open. Within this domain, an inclined plane was simulated by altering the gravity vector. Winds were represented with an atmospheric profile with simple laminar flow. A fixed (nonmoving) heat source, perpendicular to the wind flow, was located at ground level several meters from the inflow boundary along the inclined plane. Each heat source case was characterized with three variables: heat release rate per unit area $(\mathrm{kW} / \mathrm{m} 2)$, depth (width in meters) and duration in seconds. A ramp function was used to both initiate and terminate the heat source in time. Beyond the heat source, at regular $3 \mathrm{~m}$ intervals along the slope, synthetic "sensors" tracked wind velocities, temperature, radiative and total heat fluxes. We calculated convective heat fluxes through standard heat transfer coefficient calculations based on cylinder geometry with a characteristic diameter of $0.1 \mathrm{~m}$ and a length of $0.65 \mathrm{~m}$, intended to represent a person's arm.

To assess the relative contribution to potential burn injury from different heat transfer mechanisms, for each sensor over time, we calculated the thermal dosage from radiation only, from convection only, and from the two mechanisms of heat transfer combined. Thermal Dosage, $\mathrm{V}$, is calculated as $\mathrm{V}=\mathrm{tI}^{4 / 3}$ where $\mathrm{t}$ is time, $\mathrm{I}$ is total incident heat flux, and $\mathrm{V}$ is the thermal dosage, measured with Thermal Dosage Units $(\mathrm{TDU})$; one TDU $=1\left(\mathrm{~kW} / \mathrm{m}^{2}\right)^{4 / 3} . \mathrm{s}$ (Eisenberg et al 1975, Tsao and Perry 1979, Torvi et al 2000). We used three thresholds of Thermal Dosage which have been identified to correlate with burn injuries (to exposed bare skin) as follows: 550 TDU indicates onset of $1^{\text {st }}$ degree burns, a value of 1050 represents onset of $2^{\text {nd }}$ degree burns, and a value of 2300 corresponds to full depth $3^{\text {rd }}$ degree burn, as well as 50\% lethality TDU for a typical subject (Hymes et al. 1996).

Summarizing the Thermal Dosage at each sensor over the time interval extending from the start of heat release from the heat source until thirty seconds after heat release terminated, we assessed the farthest sensor from the heat source experiencing each of the three thresholds. This provided us with a means of assessing potential burn injury as a function of distance from the heat source as well as the other factors in the experiment. 


\section{Results}

Figure 2 shows a series of graphs for an individual simulation. The top three panels show convective, radiative and total incident fluxes with different coloured lines for each sensor over time. The bottom panel shows thermal dosage (for total incident heat flux) as a function of distance from the heat source for the slope and wind conditions of that simulation; different symbols correspond to different thresholds of potential injury as quantified with Thermal Dosage.
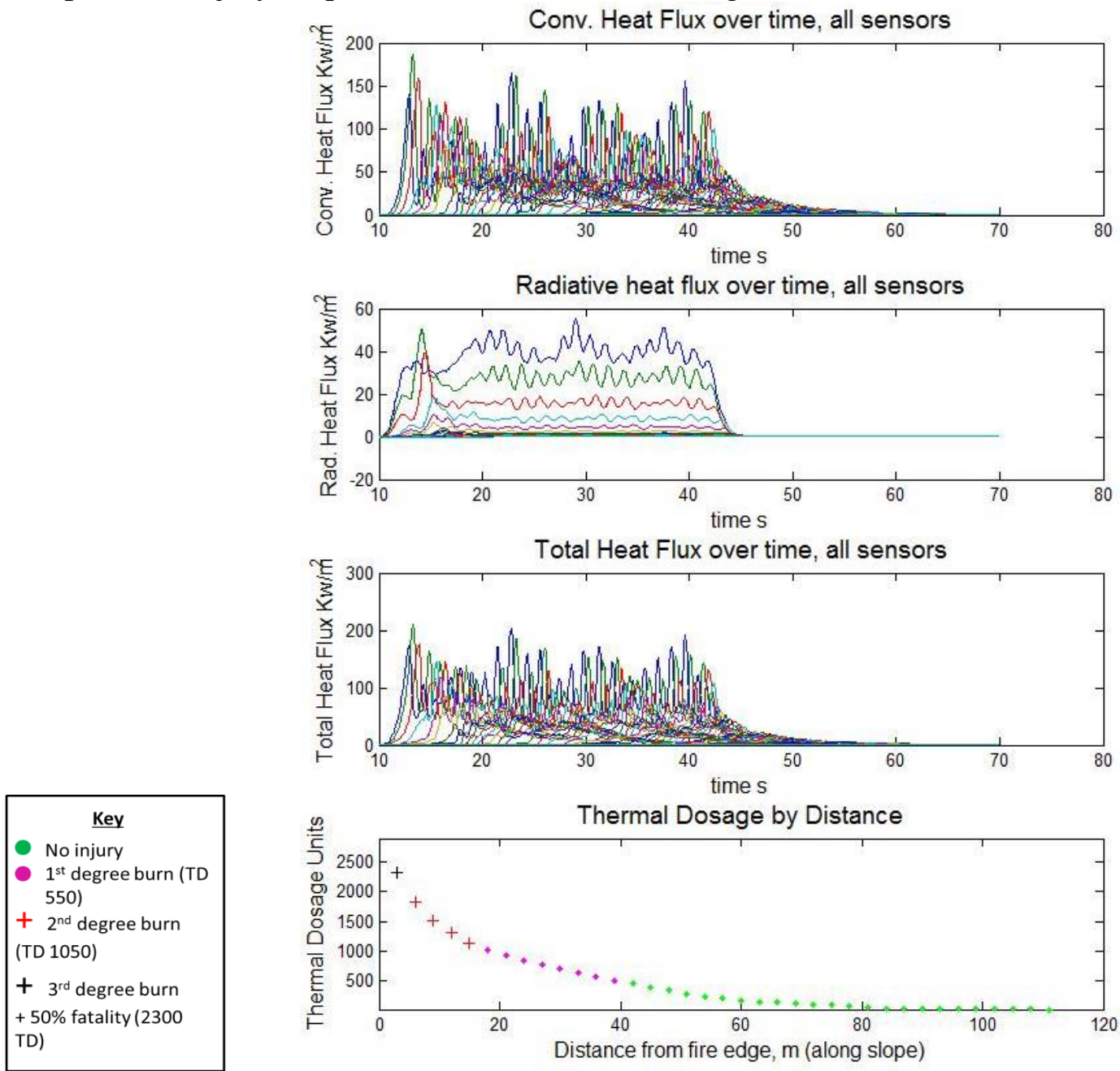

Figure 2. Simulation output for a given simulation. Top three panels show plots of convective heat flux, radiative heat flux and total heat flux over time at points spaced along the slope a fixed height above the ground. Bottom panel shows thermal dosage for each point over distance from heat source. Thermal dosages are very high close to the heat source but diminish with distance; markers in bottom panel correspond to injury key, shown above

In this example, at distances $40 \mathrm{~m}$ or greater from the heat source, no injury is predicted to occur; injuries increase as sensors approach the heat source, with 1st degree burns predicted for 18 to $39 \mathrm{~m}$, 2nd degree burns predicted from 6 to $15 \mathrm{~m}$ from the heat source, and full depth 3rd degree burns and $50 \%$ mortality predicted at distances below $6 \mathrm{~m}$.

The range of conditions examined resulted in a wide range of outcomes, with very little predicted injury under more mild heat source cases, light winds and low slopes, ranging to very extreme effects at great distances from the heat source under high winds, high slopes and more severe heat source cases. The relative contribution of radiative vs convective heat transfer to Thermal dosage varied as well with the conditions. In the case shown in Figure 2, convective heat flux was typically around twice the radiative heat flux. 
Heat fluxes from the numerical experiments were similar to values reported in measurements. For example, radiative heat flux for Figure 2 is in a similar range to values reported for measurements taken in burning pine needles and oak branches in southern France (Silvani and Morandini 2009).
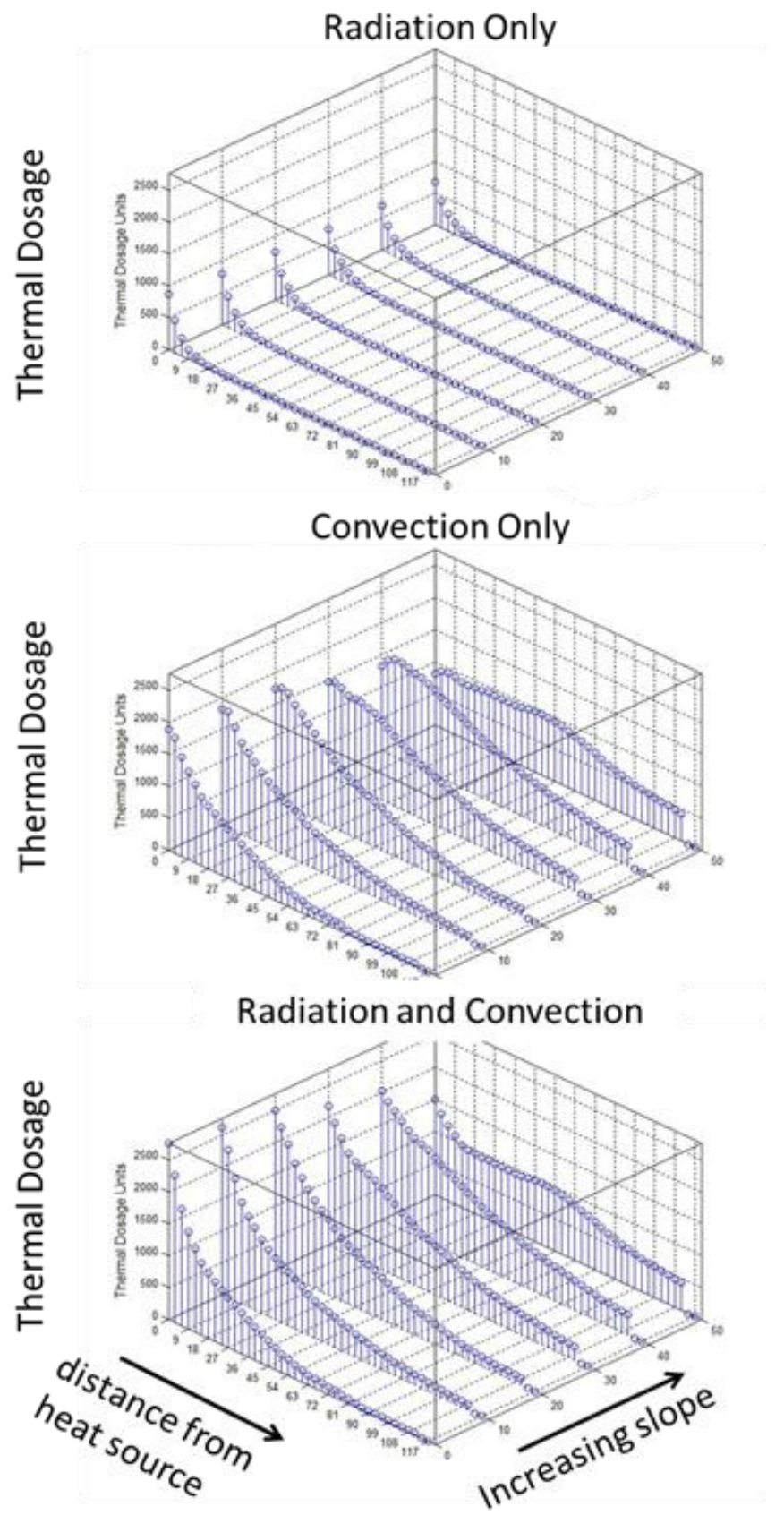

Figure 3. Simulated thermal dosage, a measure of potential burn injury, at different distances from a heat source, and on different slopes for a particular wind speed and set of heat source parameters. Top panel shows radiation, middle shows convection, and bottom shows combined effects.

All three characteristics used to describe the heat source (heat release rate per unit area, depth and duration) significantly impacted the safe separation distance; all three factors interacted with slope and wind as well. In general, Thermal Dosage increased as all three of these factors increased.

Our primary finding, however, was that inclusion of convective heat associated with wind and slope effects could result in burn injuries at distances often several multiples of what would result from radiation alone. Prior rules of thumb used for field personnel in the US, based on radiation alone, for flat ground, with no wind, would characterize safe separation distance as a multiple of four times the 
flame length (Butler and Cohen 1998a and b). In contrast, in the most extreme cases we tested, safe separation distance could potentially be nearly an order of magnitude greater, or forty times the flame length.

\section{Discussion}

We conducted a series of numerical experiments examining potential thermal exposure at a range of distances from a fixed heat source under a range of wind, slope conditions and with different heat source parameters. We found that safe separation distances may need to be much larger to ensure firefighter safety in wind and slope conditions. This has potentially significant implications for firefighting tactics, design and planning of safety zones, as well as in consideration of escape routes and the safety margins in time needed to ensure safe evacuation (Beighley 1995, Baxter et al 2004). An additional finding of potential consequence was that the characteristics of the heat source were all highly significant to predicting safe separation distance. The intense energy release rates from crown fires are certainly well known but dynamic aspects of convection arising in these intense situations could pose dangers to firefighters. For example, intense jets of superheated air have been observed in crown fire situations (Coen et al 2004). Research is needed to better characterize the frequency and magnitude of such events and their potential for firefighter injury. While most interest in fire behaviour emphasizes the active flaming front, our results suggest that heavy fuels and duff, which often burn for long duration and cover large areas, may potentially contribute sufficient energy to affect safe separation distance. We expect that, under some topographic configurations and atmospheric conditions, long burning fuels such as these, contributing energy over often large areas, could potentially result in longer safe separation distances. More research is needed to examine whether this is truly a possibility or not.

It is important to recognize that this work represents a simple early step in investigations along these lines. We expect that future work will provide greater refinement of the concepts we present here. This is a natural and expected course of how scientific knowledge unfolds. Our numerical experiments have a very simple configuration; our use of a non-moving heat source is convenient and tractable for a first approach but is not very representative of a real wildfire; more work must be carried out with moving heat sources. Additional work must be carried out as well to ensure that results such as those presented here are not highly influenced by domain width, domain size, resolution or other potential numerical artifacts. Investigation should examine how vegetation might reduce (or increase) the safe separation distance effects we observed here.

Particularly important, however, is to examine how more complex terrain configurations could influence outcomes. We expect that under many circumstances in real fires these slope/wind multipliers may be less than we observed here, as convective cooling could play a significant role. However there may be cases of particular topographic configurations that could lead to greater distance effects; this could be disastrous. Recent work suggests that particular wind/terrain alignment scenarios can have very significant effects, resulting in rapid changes in fire behavior (Sharples et al 2010, Sharples et al 2012). More research is needed to link potential burn injury to firefighters, dynamic fire behavior, and atmospheric / topographic interactions such as these.

Using a dynamic, physics-based fire model, we assessed Thermal Dosage arising from radiation alone, convection alone, and both combined. In general, measurement of convective processes can pose significant challenges in the field, typically requiring a great deal of instrumentation and often only permitting a relatively small sample of observations (Kaimal et al 1976); inferences made from point observations may result in uncertainties when applied over larger areas (Linn et al. 2012). A significant advantage of using a physics-based model, as we did here, is that these quantities, and the dynamic interactions between different influential factors, can be examined in detail, facilitating improved understanding. Such models provide a unique value in that they can provide an experience analogous to laboratory experiments; modeling efforts are uniquely complementary to physical experiments in 
laboratories and in larger field campaigns. Fire science benefits from all of these approaches to learning.

Finally, our finding that safe separation distances may need to be much larger to ensure firefighter safety in wind and slope conditions suggests a possible paradigm shift. This shift may already be underway. When we first encountered these results we were somewhat discouraged, as it seemed likely that managers might interpret these results as extremely restrictive, unreasonable, and, in many cases, unattainable, particularly in areas of complex terrain as are common throughout areas within the US and elsewhere where fires often occur. However, in presentations with several groups of managers in the United States, their response has often been quite different; some managers were encouraged that these results could provide them with justification for not sending firefighters into areas from which escape in the event of a blow-up could be very tenuous. We hope that this research, and subsequent work which follows it, may promote the use of more indirect attack tactics and other approaches which limit firefighter risk exposure.

\section{References}

Albini, FA (1986) Wildland fire spread by radiation-- a model including fuel cooling by natural convection. Combustion Science \& Technology 45, 101-113.

Beighley, M. 1995. Beyond the safety zone: creating a margin of safety. Fire Management Notes 55(4):21-24

Baxter G, Alexander M, Dakin G (2004) Travel rates of Alberta wildland firefighters using escape routes on a moderately steep slope. Forest Engineering Research Institute of Canada Advantage Report. Vol. 5 No. 25. Pointe Claire, QC and Vancouver, BC. 15 pp.

Butler, Bret W.; Bartlette, Roberta A.; Bradshaw, Larry S.; Cohen, Jack D.; Andrews, PatriciaL.; Putnam, Ted; Mangan, Richard J. 1998. Fire behavior associated with the 1994 South Canyon Fire on Storm King Mountain, Colorado. Res. Pap. RMRS-RP-9. Ogden, UT: U.S. Department of Agriculture, Forest Service, Rocky Mountain Research Station. $82 \mathrm{p}$

Butler, BW, Cohen, JD (1998a) Firefighter safety zones: how big is big enough? Fire Management Notes Vol. 58, 13-16.

Butler, BW, Cohen, JD (1998b) Firefighter safety zones: a theoretical model based on radiative heating. International Journal of Wildland Fire 8, 73-77.

Butler, BW, Cohen, J, Latham, DJ, Schuette, RD, Sopko, P, Shannon, KS, Jimenez, D, Bradshaw, LS 2004. Measurements of radiant emissive power and temperatures in crown fires. Canadian Journal of Forest Research 34, 1577- 1587.

Butler B. W. (2014) Wildland firefighter safety zones: a review of past science and summary of future needs. International Journal of Wildland Fire 23, 295-308.

Cheney, Phil, Jim Gould, and Lachie McCaw. "The dead-man zone-a neglected area of firefighter safety." Australian Forestry 64, no. 1 (2001): 45-50.

Coen, Janice, Shankar Mahalingam, and John Daily. "Infrared imagery of crown-fire dynamics during FROSTFIRE." Journal of Applied Meteorology 43, no. 9 (2004): 1241-1259.

Frankman, D, Webb, BW, Butler, BW (2010) Time-resolved radiation and convection heat transfer in combusting discontinuous fuel beds. Combustion Science \& Technology 182, 1-22.

Frankman, David, Brent W. Webb, Bret W. Butler, Daniel Jimenez, Jason M. Forthofer, Paul Sopko, Kyle S. Shannon, J. Kevin Hiers, and Roger D. Ottmar. "Measurements of convective and radiative heating in wildland fires."International Journal of Wildland Fire 22, no. 2 (2013): 157-167.

Furnish, Jim; Chockie, Alan; Anderson, Leslie; Connaughton, Kent; Dash, Dave; Duran, Joe; Graham, Brenda; Jackson, George; Kern, Tony; Lasko, Rich; Prange, Jim; Pincha-Tulley, Jeanne; Whitlock, Chuck. 2001. Thirtymile Fire. Accident Investigation Factual Report. U.S. Department of Agriculture, Forest Service. 95p Available at http://www. fs. fed. us/r6/wenatchee/fire/thirtymilereports. html 
Gettle, G, Rice, CL (2002) Criteria for determining the safe separation between structures and wildlands. In 'IV International Conference on Forest Fire Research \& Wildland Fire Safety Summit. Luso, Coimbra, Portugal', 18-23 November, 2002. (Ed. DX Viegas) pp. 9. (Millpress: Rotterdam)

Hymes, I, Boydell, W, Prescott, B (1996) 'Thermal Radiation: Physiological and pathological effects.' (Insititution of Chemical Engineers: Rugby, Warwickshire, UK)

Kaimal, J. C., J. C. Wyngaard, D. A. Haugen, O. R. Coté, Y. Izumi, S. J. Caughey, C. J. Readings, 1976: Turbulence Structure in the Convective Boundary Layer. J. Atmos. Sci., 33, 2152-2169.

Linn R., Winterkamp J., Colman J., Edminster C. and Bailey J. 2005. Modeling interactions between fire and atmosphere in discrete element fuel beds. International Journal of Wildland Fire 14: 37-48.

Linn R., Wintercamp C., Edminster C., Colman J. and Smith W. 2007. Coupled influences of topography and wind on wildland fire behavior. International Journal of Wildland Fire 16: 183-195.

Linn R.R., Reisner J., Colman J.J. and Winterkamp J. 2002. Studying wildfire behavior using FIRETEC. International Journal of Wildland Fire 11: 233-246.

Linn, Rodman, Kerry Anderson, Judith Winterkamp, Alyssa Brooks, Michael Wotton, Jean-Luc Dupuy, François Pimont, and Carleton Edminster. "Incorporating field wind data into FIRETEC simulations of the International Crown Fire Modeling Experiment (ICFME): preliminary lessons learned."Canadian Journal of Forest Research 42, no. 5 (2012): 879-898.

Mell W., Jenkins M.A., Gould J. and Cheney P. 2007. A physics-based approach to modelling grassland fires. International Journal of Wildland Fire 16: 1-22.

Mell W., Maranghides A., McDermott R. and Manzello S.L. 2009. Numerical simulation and experiments of burning douglas fir trees. Combustion and Flame 156: 2023-2041.

National Wildfire Coordinating Group [NWCG]. [N.d.].Glossary of wildland fire terminology. http://www.nwcg.gov/pms/pubs/glossary/index.htm. (June 1, 2011).

McArdle, RE (1957) Standard fire fighting orders. Fire Control Notes 18, 151-152.

Rothermel R.C. 1972. A mathematical model for predicting fire spread in wildland fuelsResearch Paper INT-115. United States Department of Agriculture, Forest Service, Intermountain Forest and Range Experiment Station,, Ogden, Utah. p. 40.

Rossi, JL, Simeoni, A, Moretti, B, Leroy-Cancellieri, V (2011) An analytical model based on radiative heating for the determination of safety distances for wildland fires. Fire Safety Journal 46, 520-527.

Sharples, J. J., R. H. D. McRae, and R. O. Weber. "Wind characteristics over complex terrain with implications for bushfire risk management." Environmental Modelling \& Software 25, no. 10 (2010): 1099-1120.

Sharples, Jason J., Richard HD McRae, and Stephen R. Wilkes. "Wind-terrain effects on the propagation of wildfires in rugged terrain: fire channelling."International Journal of Wildland Fire 21, no. 3 (2012): 282-296.

Silvani, X, Morandini, F (2009) Fire spread experiments in the field: Temperature and heat fluxes measurements. Fire Safety Journal 44, 279-285.

Torvi, DA, Hadjisophocleous, GV, Hum, J (2000) A new method for estimating the effects of thermal radiation from fires on building occupants. In 'Proceedings of the ASME Heat Transfer Division. pp. 65-72. (National Research Council Canada. Available at www.nrc.ca/irc/ircpubs

Tsao, C.K. and Perry, W.W., 1979, "Modifications to the Vulnerability Model: A Simulation System for Assessing Damage Resulting from Marine Spills (VM4)," ADA 075 231, US Coast Guard NTIS Report No. CG-D-38-79.

Viegas, D. X., L. P. Pita, L. Ribeiro, and P. Palheiro. "Eruptive fire behaviour in past fatal accidents." Proceedings, Eighth International Wildland Fire Safety Summit (2005): 26-28.

Xanthopoulos, G. 2007. Forest fire related deaths in Greece: confirming what we already know. In: Proceedings of "Wildfire 2007", Sevilla, Spain, pp. 1-12.

Zarate, L, Arnaldos, J, Casal, J (2008) Establishing safety distances for wildland fires. Fire Safety Journal 43, 565-575. 